（東京工業大學電氣化學科研究室）（昭和六年六月二五日受理）

\title{
クロム鐵鑛分解に關する研究 (第二報)
}

\section{硫酸クロムと硫酸との化合物及硫酸クロムと硫酸、二價金屬の硫酸監との化合物}

\author{
加藤與五即 - 池野 喜當
}

（此颠告の大部は故傍島清氏の實瞼を基とする）

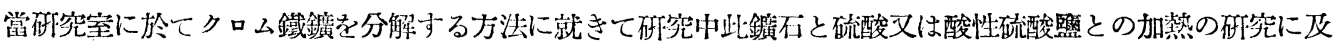

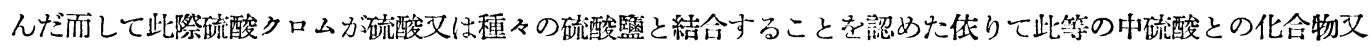

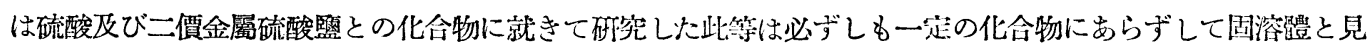
做されるものの樣である然し今は單に分析の結果に依つて得な組成を高ちに化合物の組成と見做して此所に報 类することとする

此報告をな寸に當りては之を 2 分して第一に「硫酸クロムと硫酸との化合物」第二に「硫酸ク口ムと二價金 屬硫酸監及び硫酸」の化合物に就きて記載する

\section{符一 硫酸ク口ムと硫酸との化合物}

硫酸第二クロムを硫酸と共に熱するときは此等か結合して水に難溶性の化合物を作る其化合物の組成に就き ては次の如き研究がある
$\mathrm{Cr}_{2}\left(\mathrm{SO}_{4}\right)_{3} \mathrm{r} / 2 \mathrm{H}_{2} \mathrm{SO}_{4}$
Abbeg. Handb. d. Anorg. Chem., IV.1. 2 Hälfte 152
$\mathrm{Cr}_{2}\left(\mathrm{SO}_{4}\right)_{3}{ }^{7} / 2 \mathrm{H}_{2} \mathrm{SO}_{4}$ Cross. u. Higgins, J. Chem. Soc., 41, 113
$\mathrm{Cr}_{2}\left(\mathrm{SO}_{4}\right)_{3} 1-3 \mathrm{H}_{2} \mathrm{O}\left(110-120^{\circ} \mathrm{C}\right)$
Recoura, Ann. Chim. Phys. [7] 4, 494

又高溫度では

$$
\begin{array}{lll}
\mathrm{Cr}_{2}\left(\mathrm{SO}_{4}\right)_{3} & \mathrm{x}_{2} \mathrm{H}_{2} \mathrm{SO}_{4} & \text { Etard, J. Chem.. Soc., } 39 \text { (1879A) } 104 \\
\mathrm{Cr}_{2}\left(\mathrm{SO}_{4}\right)_{3} & \mathrm{H}_{2} \mathrm{SO}_{4} & \text { Burton \& Glover, J. Soc. Leather Trades Chem., 1923, 7, } \\
& 116-21
\end{array}
$$

此等の化合物の組成及其生成條件に至つては未だ統一したものを見ない本砸究は此條件を組織立てんが篇め に企てたるものである

此矿究には第一に硫酸第二クロムを濃硫酸中に大れ之を加熱し其溫度上䒜の曲線を求め且つ諸溫度に於ける 生成物の組成を定めた

資 料 此研究に用ひたる硫酸第二クロムはメルク製品にして薄き鱗片狀の濃綠色物である其組成は $\mathrm{CrSO}_{4}$ $\mathrm{OH} \cdot 3.5 \mathrm{H}_{2} \mathrm{O}$ に應ずる又硫酸は比重1.80の純率品を用ひた

試驗法 加熱曲線を求むるには約 $5 \mathrm{~g}$ の硫酸第二クロムと約 $8 \mathrm{cc}$ の濃硫酸を硝子管に入れ其中に $500^{\circ} \mathrm{C}$ まで の目盛もる水銀塞笼計を立て其硝子管を小型のニクロム線捲電氣㠠內に置いて加熱し各時間に應ずる溫度を讀 んだ但し此方法は本誌（昭和 3 年 363 號、455頁)に記載せる所と同樣である

又硫酸クロムと硫酸との混合物を熱して得た生成物の組成を定めるには其を水洗して先づニッァル坩堝內に て過酸化ナトリウムと低赤熱に加熱しクロムをクロム酸既となし次に此溶液からクロムは之を點滴法にて定め 硫酸は之を重量法にて定めた

宽駼結果 上の如くにして得たる賽驗結果を次に揭げる

(一)硫酸クロムと硫酸との加熱 片狀硫酸第二クロム(含水)と濃硫酸とを上に說明せる如くして加熱し時間 
と溫度との關係を定めた此關係を圖示すれば第一圖の如くでせる

之に依れば約 $250^{\circ} \mathrm{C}$ 及び約 $280^{\circ} \mathrm{C}$ に於て特殊の属曲もるを見る

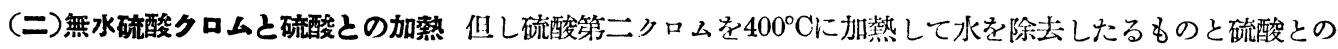
混合物の加熱關係を求めたるに約 $280^{\circ} \mathrm{C}$ に於て屚曲を胃たのみである之を圆示すれば第二圆の如くである

(三)硫酸クロムの加熱曲線 又片㓠硫酸クロム $(10 \mathrm{~g})$ のみを右と同樣に加熱せる場合の瀿度と時間との關係 を求めたるに約 $120^{\circ} \mathrm{C}$ に於て吸熱の屈曲もり其より $350^{\circ} \mathrm{C}$ 附近迄虫曲らしきものを見ない此關係を顝示寸れ ば第三䦌の期くである
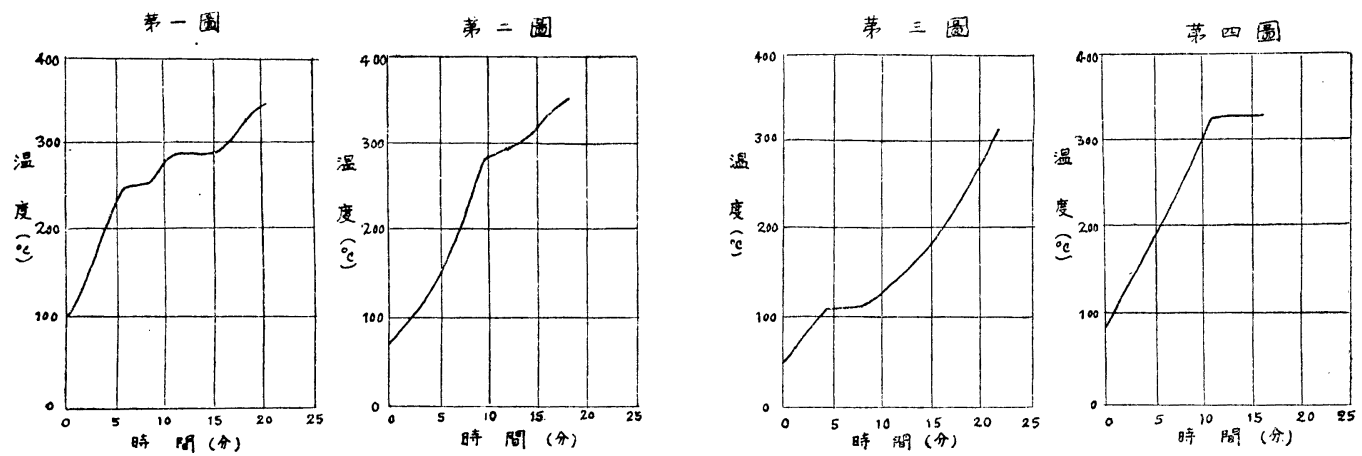

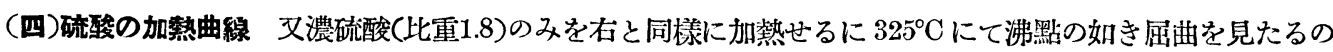

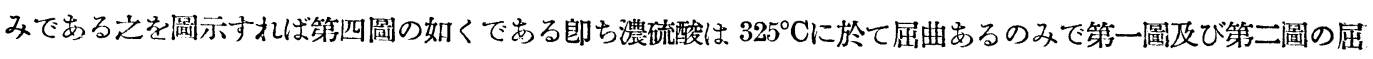
曲に應ずるものがない

故に加熱曲線に依りて見る時は $250^{\circ} \mathrm{C}$ 及 $280^{\circ} \mathrm{C}$ 附近の屈曲線は硫酸クロムと硫酸との 結合の吸熱に外なら ずと見得られる依りて次には此等の溫度に於て生成せるものを化合物と見做して其組成を跨究した

生成物の組成

數多の實諭に於て $250^{\circ} \mathrm{C}$ 以下於ては硫酸クロムと硫酸の溶液は緑色なるも $250^{\circ} \mathrm{C}$ 以上に於ては常に桃色の沈 澱の生成を見た阿して又其沈澱の色は溫度の上昇と共に盆了鮮明となるを見た此沈澱を椧却すれば $270^{\circ} \mathrm{C}$ 附近 に熱したるものは灰色となり $300^{\circ} \mathrm{C}$ 附近に加熱したるものは淡桃灰色となる從て $270^{\circ} \mathrm{C}$ 以にて生成せる沈澱 と $300^{\circ} \mathrm{C}$ 附近まで熱し:て得たる沈汇とは別物の如くである依つて此等雨種のものに就いて其組成を定めた

$\begin{array}{lccc} & \mathrm{Cr} \% & \mathrm{SO}_{4} \% & \mathrm{SO}_{4} / \mathrm{Cr} \\ 1 . & 20.64 & 78.86 & 2.07 \\ 2 . & 19.86 & 76.60 & 2.08 \\ 3 . & 19.50 & 74.20 & 2.06\end{array}$

分子式(平均值) $\mathrm{Cr}_{2}\left(\mathrm{SO}_{4}\right)_{3} 1.12 \mathrm{H}_{2} \mathrm{SO}_{4}$

$270^{\circ} \mathrm{C}$ に硫酸クロム(含水)と硫酸とを長く熱して生成 せられた物質を水にて能く洗淡して其クロムと硫酸との 制合を定めたるに左の結果を得た

郎ち此化合物は略 $\mathrm{Cr}_{2}\left(\mathrm{SO}_{4}\right)_{3} \mathrm{H}_{2} \mathrm{SO}_{4}$ の組成を有することに當る之は $250^{\circ} \mathrm{C}$ は硫酸クロムと硫酸とが化合 して此組成のものとなることを示すものの如くである

\begin{tabular}{lclc} 
& $\mathrm{Cr} \%$ & $\mathrm{SO}_{4} \%$ & $\mathrm{SO}_{4} / \mathrm{Cr}$ \\
1. & 25.31 & 70.21 & 1.5 \\
2. & 24.50 & 67.99 & 1.5 \\
3. & 22.80 & 77.72 & 1.85 \\
4. & 21.33 & 74.13 & 1.88 \\
分子式 & 1,2 & \multicolumn{2}{c}{$\mathrm{Cr}_{2}\left(\mathrm{SO}_{4}\right)_{3}$} \\
\multicolumn{2}{l}{} & 3,4 & $\mathrm{Cr}_{2}\left(\mathrm{SO}_{4}\right)_{3} 0_{6} 6 \mathrm{H}_{2} \mathrm{SO}_{4}$
\end{tabular}

次に硫酸クロム(含水)と硫酸とを $300^{\circ} \mathrm{C} に$ 長く熱して 生じたる物質を分析したるに其結果左の如くである 此結果は硫酸中に充分長く熱すれば無水硫酸クロムと なるを示するのの如くである 3,4 の結果は其反應の中途 の物質と考ふるを至當と思はる之れに依れば硫酸クロム 
と硫酸と $250^{\circ} \mathrm{C}$ 附近にて結合をなしたるものが $280^{\circ} \mathrm{C}$ 附近にて又分解するのである又無水硫酸クロム $\left(400^{\circ} \mathrm{C}\right.$

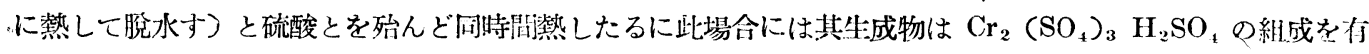
するを見た $\mathrm{H}_{2} \mathrm{SO}_{4}$ の分離する反應の遲緩なる理由は未ナ゙明嘹でない

不可逆性

硫酸クロムの加熱にて起る反應には與味せる不可逆性がある今之を列擧する

(1) 上に揭げたる $280^{\circ} \mathrm{C}$ 附近に於ける

$$
\mathrm{Cr}_{2}\left(\mathrm{SO}_{4}\right)_{3} \mathrm{H}_{2} \mathrm{SO}_{4}=\mathrm{Cr}_{2}\left(\mathrm{SO}_{4}\right)_{3}+\mathrm{H}_{2} \mathrm{SO}_{4}
$$

なる反應は容易に淮行すれども此逆行は容易でない元來此歱の反應は可逆にして僅かの渻度の差にて逆行し易 き如く想像せらる郎ち $290^{\circ} \mathrm{C}$ 附近にて生成せる物質を $\mathrm{H}_{2} \mathrm{SO}_{4}$ と $270^{\circ} \mathrm{C}$ 附近に保てば”商易に $\mathrm{Cr}_{2}\left(\mathrm{SO}_{4}\right)_{3} \mathrm{H}_{2} \mathrm{SO}_{4}$ となる如く思はる然るに事實は之に反して此結合反應は容易でない

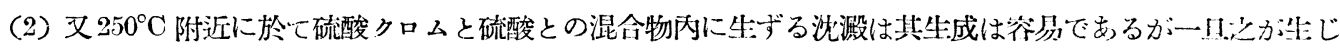
たる上は其れと硫酸との混合物を $240^{\circ} \mathrm{C}$ に保つも其溶解は容易でない

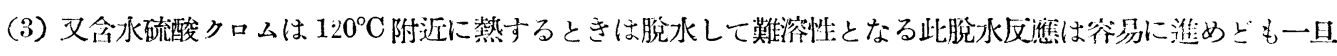
斯樣にして生じたる無水物は之を沸撙水中に長く置きても其吸水溶解は容易でない郎ち硫酸クロムが水又は硫 酸を央ふは淮み易く其逆行は淮め踑き事は硫酸クロムの一特質の如く見へて與味ありと思はれる

上の關倸もるが䉆めに第一圖の硫酸クロムと硫酸との混合物の加熱曲線又は含水硫酸クロムの加熱曲緗（本 交には揭げず)には階段即ら急曲を認め得たれども冷却曲線には此等に應ずる急曲を認め得なかつた

總括及び結諭

以上の害驗に依机ば次の結論をなし得ら机る

(1) $250^{\circ} \mathrm{C}$ 附近にては硫酸溶液內にて多警の硫酸分子と結合せるものか硫酸分子をを头らて $\mathrm{Cr}_{2}\left(\mathrm{SO}_{4}\right)_{3} \mathrm{H}_{2}$

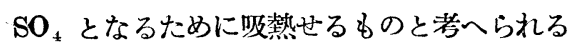

(2) $280^{\circ} \mathrm{C}$ 附近は

$$
\mathrm{Cr}_{2}\left(\mathrm{SO}_{4}\right)_{3} \mathrm{H}_{2} \mathrm{SO}_{4} \rightleftarrows \mathrm{Cr}_{2}\left(\mathrm{SO}_{4}\right)_{3}+\mathrm{H}_{2} \mathrm{SO}_{4}
$$

なる反應の轉移品なる事は明かである從つて又此硫酸の分雔が吸熱反應なることも明であらう

(3) $400^{\circ} \mathrm{C}$ に加熱して脫水せる硫酸クロムと硫酸との混合物の加熱曲線には $250^{\circ} \mathrm{C} に$ 於て急曲を認め奴之れし此 物質か $350^{\circ} \mathrm{C}$ 以ににて硫酸に溶解して之と結合与る速度小にて $\mathrm{H}_{2} \mathrm{SO}_{4}$ を多く含む物質が淮液中に多く存在しな いからである然るに此以上の溫度にて $\mathrm{Cr}_{2}\left(\mathrm{SO}_{4}\right)_{3} \mathrm{H}_{2} \mathrm{SO}_{4}$ は生成せられて此 $280^{\circ} \mathrm{C}$ 附近の脫酸の吸熱反應は 加熱曲線に現はれたこと已䜠の如くである

（4）硫酸クロムと硫酸とにて $250^{\circ} \mathrm{C}$ 以上にて蜼溶性化合物をなすことは硫酸にてクロム鐵鎴を滚解せしもる ための溫度決定には重要なる意義を有す郎ち此溫度以上にては此溶解に故障を生ずるは明かである

(5) $290^{\circ} \mathrm{C}$ 以上にて硫酸クロムは硫酸液中にありて無水の難溶性 $\mathrm{Cr}_{2}\left(\mathrm{SO}_{4}\right)_{3}$ を生ずることも注意すべきこ

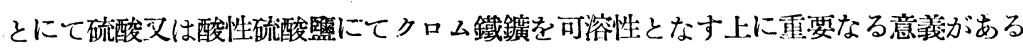

\section{第二: 硫酸クロムと二價金屬硫酸䍀との化合物}

エタール(Etard, J. Chem. Soc., 104, 39, 1879. A; Compt. rend., 87, 602-604, 1879) は硫酸クロム水溶液 と硫酸を $200^{\circ} \mathrm{C}$ 熱して $\mathrm{Cr}_{2}\left(\mathrm{SO}_{4}\right)_{3} \mathrm{MSO}_{4} n \mathrm{H}_{2} \mathrm{SO}_{4}$ の如き化命物の生ずることを示した硫酸クロムと二價金 
蜀の硫酸整との混合物を更に高温度に熱するときは此等の化合物が生成せらる之を水にて洗源するも容易に分

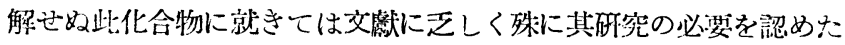

製 法 二價金屬の硫酸眮と硫酸クロムとの化合物を作るには 1 式量の監基性硫酸クロムと約 3 式量の二價

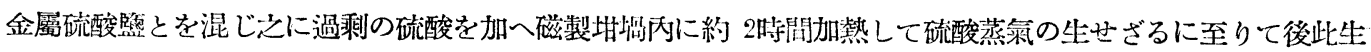
成物をよく水㗪した

該化合物の一般性诈 石の如くして製した硫酸クロムと二㵋金屬硫酸監との化合物は多くは淡灰色の粉末に

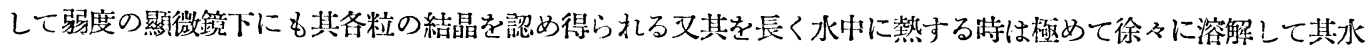
を僅に紽青色となす

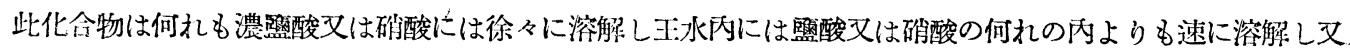
この化合物は濃硫酸には速に溶解する

䂰 究 法

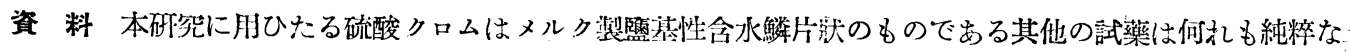
るものを選んだ

而して上記の如くして多くの化合物を製し之を充分水洗して分析を行ふた今其成績を次に說明する

(一)硫酸銅之の化合物 硫酸銅と硫酸ク口ムとの化 合物は稍緂色を帶びさ灰色にして硫酸には㴦解し難 、其組成は次の如くである

\begin{tabular}{|c|c|c|c|c|}
\hline \multirow{3}{*}{ 百分量 } & & $\mathrm{Cr}$ & $\mathrm{Cu}$ & $\mathrm{SO}_{4}$ \\
\hline & No.1 & $19.2 \%$ & $6.73 \%$ & $69.1 \%$ \\
\hline & No.2 & $17.75 \%$ & $5.94 \%$ & $63.8 \%$ \\
\hline \multirow[t]{2}{*}{ 式 比 } & No.1 & 1 & 0.287 & 1.95 \\
\hline & No.2 & 1 & 0.273 & 1.95 \\
\hline & $\begin{array}{l}\text { No.1 } \\
\text { No.2 }\end{array}$ & $\left.{ }_{4}\right)_{0}$ & $\begin{array}{l}\mathrm{r}_{2} \text { (SO } \\
\mathrm{r}_{2} \text { (SO }\end{array}$ & $\begin{array}{l}\left.\mathrm{SO}_{4}\right)_{0.3} \\
\left.\mathrm{SO}_{4}\right)_{0.3}\end{array}$ \\
\hline
\end{tabular}

(二硫酸亞鉛之の化合物 硫酸亞釦と硫酸ク口ムと の化合物は淡灰色にして上記の酸に殊によく旒解す る其分析の結果は次の如くである

\begin{tabular}{|c|c|c|c|c|}
\hline \multirow{3}{*}{ 百分量 } & & $\mathrm{Cr}(\%)$ & $\mathrm{Zn}(\%)$ & $\mathrm{SO}_{4}(\%)$ \\
\hline & No.1 & 16.46 & 10.33 & 66.71 \\
\hline & No:2 & 16.44 & 7.21 & 66.79 \\
\hline \multirow[t]{2}{*}{ 式 比 } & No.1 & 1 & $: 0.5$ & 2.2 \\
\hline & No.2 & 1 & $: 0.36$ & $: \quad 2.2$ \\
\hline & $\begin{array}{l}\text { No.1 } \\
\text { No.2 }\end{array}$ & $\begin{array}{l}\left.\mathrm{SO}_{4}\right) \\
\left.\mathrm{SO}_{4}\right)\end{array}$ & $\begin{array}{l}\mathrm{Cr}_{2} \text { (SO } \\
\mathrm{Cr}_{2} \text { (SO }\end{array}$ & $\begin{array}{l}\left.\mathrm{H}_{2} \mathrm{SO}_{4}\right)_{0.4} \\
\left.\mathrm{H}_{2} \mathrm{SO}_{4}\right)_{0}\end{array}$ \\
\hline
\end{tabular}

(三)硫酸コハルトとの化合物 硫酸コバルトの化命 物は淡紅灰色にして上記諸酸に殊によく溶解する其 分析の結果次次の姐くでもる

\begin{tabular}{|c|c|c|c|c|}
\hline \multirow{3}{*}{ 百分骨 } & & $\mathrm{Cr}$ & $\mathrm{Co}$ & $\mathrm{SO}_{4}$ \\
\hline & No.l & 16.45 & 7.57 & 71 \\
\hline & No.2 & 18.01 & 7.14 & 70 \\
\hline 式 比 & No.1 & 1 & 0.41 & \\
\hline
\end{tabular}

化學式 No.1 $\left(\mathrm{CoSO}_{4}\right)_{0.82} \mathrm{Cr}_{2}\left(\mathrm{SO}_{4}\right)_{3}\left(\mathrm{H}_{2} \mathrm{SO}_{4}\right)_{0.92}$ $\mathrm{No.2}\left(\mathrm{CoSO}_{4}\right)_{0.70} \mathrm{Cr}_{2}\left(\mathrm{SO}_{4}\right)_{3}\left(\mathrm{H}_{2} \mathrm{SO}_{4}\right)_{0.54}$

(四)硫酸カドミウムとの化合物 硫酸カドミウムと の化合物は青色にして其分析の結果は次の如くで出 る

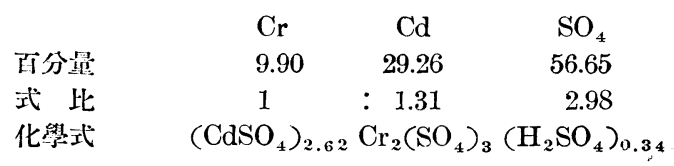

(五)硫酸マグネシウムとの化合物 硫酸マグネシウ ムとの化合物は灰色にして其分析の結果次の如くで まる

\begin{tabular}{|c|c|c|c|c|}
\hline \multirow{3}{*}{ 百分量 } & & $\mathrm{Cr}$ & $\mathrm{Mg}$ & $\mathrm{SO}_{4}$ \\
\hline & No.1 & 16.45 & 3.70 & 72.14 \\
\hline & No. 2 & 16.31 & 3.84 & 72.90 \\
\hline \multirow{2}{*}{ 式 此 } & No.1 & 1 & 0.48 & 2.37 \\
\hline & No.2 & 1 & $: 0.5$ & 2.42 \\
\hline 化學式 & $\begin{array}{l}\text { No.1 } \\
\text { No.2 }\end{array}$ & $\begin{array}{l}\left.\mathrm{IgSO}_{4}\right) \\
{\left[\mathrm{gSO}_{4}\right)}\end{array}$ & $\begin{array}{l}\mathrm{Cr}_{2} \text { (SO } \\
\mathrm{Cr}_{2} \text { (SC }\end{array}$ & $\begin{array}{l}\left(\mathrm{H}_{2} \mathrm{SO}_{4}\right)_{0.78} \\
\left(\mathrm{H}_{2} \mathrm{SO}_{4}\right)_{0.8}\end{array}$ \\
\hline
\end{tabular}

(六)硫酸アムモニウム第一鐵との化合物 硫酸アム モニウム第一鐵との化命物は淡䋺灰色にして其分析 の結果次の対くである

\begin{tabular}{|c|c|c|c|c|}
\hline \multirow{3}{*}{ 百分量 } & & $\mathrm{Cr}$ & $\mathrm{Fe}$ & $\mathrm{SO}_{4}$ \\
\hline & No.1 & 9.15 & 13.35 & 67.53 \\
\hline & No.2 & 7.39 & 14.78 & 68.66 \\
\hline \multirow[t]{2}{*}{ 式 比 } & No.1 & 1 & $: 1.36$ & 4.00 \\
\hline & No.2 & 1 & $: 1.74$ & 5.03 \\
\hline
\end{tabular}


化學式 No.1 $\mathrm{Cr}_{2}\left(\mathrm{SO}_{4}\right)_{3}\left(\mathrm{FeSO}_{4}\right)_{2.7}\left(\mathrm{H}_{2} \mathrm{SO}_{4}\right)_{2.3}$ $\mathrm{Cr}_{2}\left(\mathrm{SO}_{4}\right)_{3}\left\{\mathrm{FeSO}_{4}\left(\mathrm{NH}_{4}\right)_{2} \mathrm{SO}_{4}\right\}_{2.7}$ No.2 $\mathrm{Cr}_{2}\left(\mathrm{SO}_{4}\right)_{3}\left(\mathrm{FeSO}_{4}\right)_{3}\left(\mathrm{H}_{2} \mathrm{SO}_{4}\right)_{3.5}$ $\mathrm{Cr}_{2}\left(\mathrm{SO}_{4}\right)_{3}\left\{\mathrm{FeSO}_{4}\left(\mathrm{NH}_{4}\right)_{2} \mathrm{SO}_{4}\right\}_{3}$ $\left(\mathrm{H}_{2} \mathrm{SO}_{4}\right)_{0.5}$

（七）硫酸マンガンとの化合物 稍青色を帶びたる灰 色にして其分析の結果次の如くである

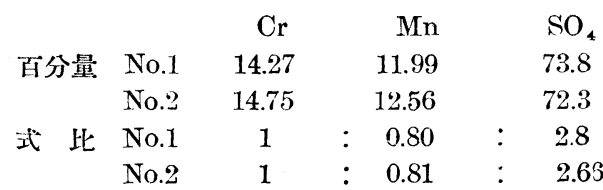

化學式 No.1 $\left(\mathrm{MnSO}_{4}\right)_{1.6} \mathrm{Cr}_{2}\left(\mathrm{SO}_{4}\right)_{3}\left(\mathrm{H}_{2} \mathrm{SO}_{4}\right)$ No.2 $\left(\mathrm{MnSO}_{4}\right)_{1.6} \mathrm{Cr}_{2}\left(\mathrm{SO}_{4}\right)_{3}\left(\mathrm{H}_{2} \mathrm{SO}_{4}\right)_{0.7}$

以上化斅式の總括 以上行ひたる諸化合物の分析結 果及び其れより計算して定めた化學式を互に比較に 便にする筑め一表とする

\begin{tabular}{|c|c|c|}
\hline$\left\{\begin{array}{l}\mathrm{Cr}_{2}\left(\mathrm{SO}_{4}\right)_{3} \\
\mathrm{Cr}_{2}\left(\mathrm{SO}_{4}\right)_{3}\end{array}\right.$ & $\begin{array}{l}\left(\mathrm{CuSO}_{4}\right)_{0.57} \\
\left(\mathrm{CuSO}_{4}\right)_{0.55}\end{array}$ & $\begin{array}{l}\left(\mathrm{H}_{2} \mathrm{SO}_{4}\right)_{0.32} \\
\left(\mathrm{H}_{2} \mathrm{SO}_{4}\right)_{0.36}\end{array}$ \\
\hline$\left\{\begin{array}{l}\mathrm{Cr}_{2}\left(\mathrm{SO}_{4}\right)_{3} \\
\mathrm{Cr}_{2}\left(\mathrm{SO}_{4}\right)_{3}\end{array}\right.$ & $\begin{array}{l}\left(\mathrm{ZnSO}_{4}\right)_{0.72} \\
\left(\mathrm{ZnSO}_{4}\right)\end{array}$ & $\begin{array}{l}\left(\mathrm{H}_{2} \mathrm{SO}_{4}\right)_{0.68} \\
\left(\mathrm{H}_{2} \mathrm{SO}_{4}\right)_{0.4}\end{array}$ \\
\hline$\left\{\mathrm{Cr}_{2}\left(\mathrm{SO}_{4}\right)_{3}\right.$ & $\left(\mathrm{CoSO}_{4}\right)_{0.82}$ & $\left(\mathrm{H}_{2} \mathrm{SO}_{4}\right)_{0.92}$ \\
\hline $\mathrm{lCr}_{2}\left(\mathrm{SO}_{4}\right)_{3}$ & $\left(\mathrm{CoSO}_{4}\right)_{0.7}$ & $\left(\mathrm{H}_{2} \mathrm{SO}_{4}\right)_{0.52}$ \\
\hline $\mathrm{Cr}_{2}\left(\mathrm{SO}_{4}\right)_{3}$ & $\left(\mathrm{CdSO}_{4}\right)_{2.62}$ & $\left(\mathrm{H}_{2} \mathrm{SO}_{4}\right)_{0.34}$ \\
\hline$\left\{\begin{array}{l}\mathrm{Cr}_{2}\left(\mathrm{SO}_{4}\right)_{3} \\
\mathrm{Cr}_{2}\left(\mathrm{SO}_{4}\right)_{3}\end{array}\right.$ & $\begin{array}{l}\left(\mathrm{MgSO}_{4}\right)_{0.96} \\
\left(\mathrm{MgSO}_{4}\right)\end{array}$ & $\begin{array}{l}\left(\mathrm{H}_{2} \mathrm{SO}_{4}\right)_{0.78} \\
\left(\mathrm{H}_{2} \mathrm{SO}_{4}\right)_{0.8}\end{array}$ \\
\hline$\left\{\begin{array}{l}\mathrm{Cr}_{2}\left(\mathrm{SO}_{4}\right)_{3} \\
\mathrm{Cr}_{2}\left(\mathrm{SO}_{4}\right)_{3}\end{array}\right.$ & $\begin{array}{l}\left(\mathrm{FeSO}_{4}\right)_{2.7} \\
\left(\mathrm{FeSO}_{4}\right)_{3}\end{array}$ & $\begin{array}{l}\left(\mathrm{H}_{2} \mathrm{SO}_{4}\right)_{2.3} \\
\left(\mathrm{H}_{2} \mathrm{SO}_{4}\right)_{3.5}\end{array}$ \\
\hline
\end{tabular}

$$
\left\{\begin{array}{lll}
\mathrm{Cr}_{2}\left(\mathrm{SO}_{4}\right)_{3} & \left(\mathrm{MnSO}_{4}\right)_{1.6} & \left(\mathrm{H}_{2} \mathrm{SO}_{4}\right)
\end{array}\right.
$$$$
\left\{\begin{array}{lll}
\mathrm{Cr}_{2}\left(\mathrm{SO}_{4}\right)_{3} & \left(\mathrm{MnSO}_{4}\right)_{1.6} & \left(\mathrm{H}_{2} \mathrm{SO}_{4}\right)_{0.7}
\end{array}\right.
$$

上の結果を見るときは五に一致すへくして然も互 に一致せ奴ものがある此原因は資料として用ひた含 水硫酸ク口ムが充分硫酸と作肘する機會を得なかつ たのではないかとの疑もある

依つて本政究に於ては硫酸クロムと他の二價金屬 硫酸監の過剩 (硫酸クロムの約 3 倍の重量)とを混じ 先づ全部を一旦最少量の水に溶解せしめ之に過剩の 䀼硫酸を加へ其を蒸弡し 硫酸蒸氣の出なくなつた時 生ずる化合物に就いても試驗した此化命物を水で洗 策して分析を行ひたる結果を次に示寸

\section{(八)硫酸亞鉛之の化合物}

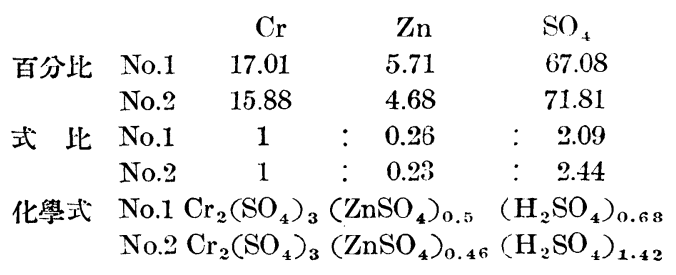

\section{(九)硫酸銅之の化合物}

\begin{tabular}{|c|c|c|c|c|}
\hline \multirow{3}{*}{ 百分比 } & & $\mathrm{Cr}$ & $\mathrm{Cu}$ & $\mathrm{SO}_{4}$ \\
\hline & No.1 & 19.34 & 7.59 & 70.76 \\
\hline & No.2 & 15.13 & 10.57 & 67.67 \\
\hline \multirow[t]{2}{*}{ 式 此 } & No.1 & 1 & 0.304 & 1.98 \\
\hline & No.2 & 1 & 0.57 & 2.42 \\
\hline t & $\begin{array}{l}\text { No.1 } \\
\text { No.2 }\end{array}$ & $\mathrm{CSO}_{4}$ & $\left(\mathrm{CuSO}_{4}\right)$ & $\begin{array}{l}\left(\mathrm{H}_{2} \mathrm{SO}_{4}\right) \\
\left(\mathrm{H}_{2} \mathrm{SO}_{4}\right)\end{array}$ \\
\hline
\end{tabular}

上の (8)，(9)の化合物の踏究より判遜するに一致すべくして一致せざるものあること明である故に上記(1) 一(7)の化合物に不一致めるも之は本研究法の如く硫酸クロムと $\mathrm{M}^{\mathrm{II}} \mathrm{SO}_{4}$ の固體を濃硫酸中に䓡したるが䉆の 又ではない事が分る

總括及び絬論

本稿の第二政究(第一の政究の總括は其れの終に記載した)である硫酸クロムと $\mathrm{M}^{\mathrm{N}} \mathrm{SO}_{4}$ と硫酸とを熱し硫酸 蒸氣の生せざるに至るときに生ずる化合物に就きて試騟せる結果を總括すれば次の如くである

(1) $\mathrm{Cr}_{2}\left(\mathrm{SO}_{4}\right)_{3}$ に結合せる同一の $\mathrm{M}^{\mathrm{IISO}}{ }_{4}$ の數は互に一致せるものがある又此數の一致せ好ものもある 又其れに結合せる $\mathrm{H}_{2} \mathrm{SO}_{4}$ も同樣である

(2) $\mathrm{Cr}_{2}\left(\mathrm{SO}_{4}\right)_{3}$ に結合せる異種 $\mathrm{M}^{\mathrm{I}} \mathrm{SO}_{4}$ の數は互に一致せざるものが多い

(3) 本研究の範園に於ては次の如き化合物がある

$$
\mathrm{Cr}_{2}\left(\mathrm{SO}_{4}\right)_{3}\left(\mathrm{M}^{\mathrm{IISO}}\right)_{4.6-3}\left(\mathrm{H}_{2} \mathrm{SO}_{4}\right)_{0.3-3.5}
$$

此等の化學式の相違に就きては㓊研究の餘地嘍多ある可きである 
（5）分析書にはクロム鐵鏬を酸性硫酸盟と混じて所謂熔融をなすには硫酸蒸氣の發生を了へて後に操作を 止むることと記載せらる故に本硎究に得たる如き化合物の生成むるべきである

從て酸性硫酸籃とクロムとを熔融して生成物を水に溶解せしむるためには數多注意の必㴗なることを推知し 得ら礼る

（東京工業大學電氣化學科呼究空）（昭和六作六月二五日受理）

\title{
二酸化マンカンの製造試驗 (第三報) \\ 天然及人エニ酸化マンガンの種類之其等の化學的及物理的諸性質の關係
}

\author{
加藤與五郎 ・ 松橋 太郎
}

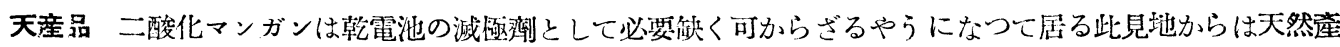
二酸化マンガンの主なるものは次の如く教へられる

\begin{tabular}{|c|c|c|c|}
\hline 種 & 類 & 硬 度 & 而して乾電池製造には軟マンガン鑛が最も多く用ひら \\
\hline 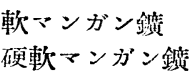 & $\begin{array}{l}\text { Pyrolusite } \\
\text { Polianite }\end{array}$ & $\begin{array}{l}2 \\
6\end{array}$ & て硬軟マンガン鑛は殆んど用ひられぬ \\
\hline 硬マンガン鏳 & Poilomelane & 6.25 & 〉なつて居る殊に硬マンガン鈸は全く考 \\
\hline
\end{tabular}

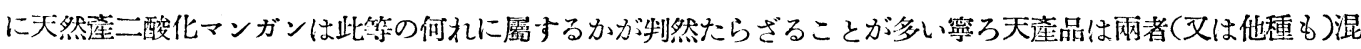
合して居るのが普通の樣に見える

雨者又は上記三者が假に別々になつて居つても其れを判然と區別することが容易でない鈸物學的の區別なら ば結晶系に依ることは普通である然るに軟マンガン鈸は高含水物の脫水にて生じたるものとも考へられ其結晶

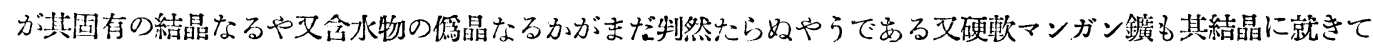
は軟マンガン鍰と類した疑跕があるフェラリ(A. Ferrari, Chem. Abst., 1926, 20, 1926)の X 線試驗の結果に 依れば二酸化マンガンは結晶上よりは單に一種なることを示して居る（此品に就きては咑究中であるから何れ 發表する)

然らば上の兩種 (丈は 3 種) の識別上殘るは水分と硬度になる然るに含水量は軟マンガン鑛でも少ないので (2\%附近が多い) そを以つて完全なる判斷の具とすることは頗る困䧼である然らば残るは硬度であるが之又完 全な制別の尺後とは思はれぬ

人工品 人工的に二酸化マンガンを製する方法は數多むる之を大別するときは濕式法と乾式法とに分つこと が出來る濕式法は水中にて之を生成せしむる方法にて乾式法は然らず今已に知られて居る諸製法を分つときは 次の樣なのがある

瀑式法 $\left\{\begin{array}{l}\text { 溶液より酸化にて沈澱せしも己法 } \\ \text { 沈䬦せる低級酸化物の酸化 } \\ \text { 溶液の雪解に依るもの }\end{array}\right.$

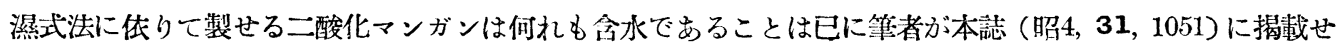
る所である

乾式法に依りて製せる二酸化マンガン中硝酸監の灼熱に依るものは無水物である然るに觸媒の存在にて低級 酸化マンガンの酸化法なる筆者考案の方法に依りて製せるものも又無水なるに似たり然れども此方法の製品は 